\title{
LITERASI LEARNING ORGANIZATION PADA PENGURUS PERSAUDARAAN MUSLIMAH (SALIMAH) KOTA BANDAR LAMPUNG
}

\author{
Ani Agus Puspawati ${ }^{1 *}$, Vina Karmilasari ${ }^{2}$, Susana Indriyati Caturiani ${ }^{3} \&$ Rahayu Sulistiowati $^{4}$ \\ 1,2,3,4 Jurusan Administrasi Publik, FISIP, Universitas Lampung \\ Jl. Prof. Dr. Sumantri Brodjonegoro No. 1, Gedungmeneng, Bandar Lampung, Lampung, Indonesia \\ *Korespondensi: ani.wardianto@gmail.com
}

\begin{abstract}
Abstrak
Literasi learning organization pada pengurus Persaudaraan Muslimah (Salimah) Kota Bandar Lampung bertujuan untuk 1) Meningkatkan partisipasil keaktifan pengurus daerah dan anggota Salimah Kota Bandar Lampung. 2) Meningkatkan efektivitas program kerja sehingga dapat berjalan dengan baik. 3) Membentuk sinergitas program antara pengurus cabang dan pengurus daerah. Metode yang dilakukan terdiri dari tiga tahapan: 1) Analisis situasi dilakukan melalui penelusuran penelitian dan kajian tema yang berkaitan. 2) Intervensi Objek: dengan ceramah -tema ceramah: a) Mental model dan personal mastery; b) Shared vision, team learning; dan c) Komunikasi efektif-, focus group discussion, dan pendampingan. 3) Evaluasi dan Refleksi. Secara kuantitatif nilai rata-rata peserta sebelum dilaksanakan kegiatan adalah 70,19 dan mengalami kenaikan menjadi 80,31 setelah dilaksanakan kegiatan pelatihan. Kenaikan rata-rata sebesar 10,12 poin.
\end{abstract}

Kata kunci: learning organization, Salimah

\section{ANALISIS SITUASI}

Organisasi masyarakat (ormas) Persaudaraan Muslimah (Salimah) memaklumatkan diri sebagai organisasi wanita yang konsen memberikan manfaat dalam menghadapi persoalan bangsa melalui visi "menjadi ormas perempuan yang kokoh dan dinamis dalam meningkatkan kualitas hidup perempuan anak dan keluarga Indonesia". Visi tersebut kemudian diturunkan dalam bentuk tugas kepengurusan ormas salimah yang meliputi: 1) mendirikan struktur, mengokohkan serta meluaskan struktur kepengurusan daerah hingga cabang; 2) mengasah keterampilan mengelola diri, mengelola organisasi sekaligus mengelola rumah tangga; 3) merencanakan dan mengimplementasikan berbagai program yang dibutuhkan masyarakat; 4) berjejaring dengan berbagai elemen masyaarakat serta institusi; 5) mendokumentasikan dan mempublikasikan berbagai kegiatan; dan 6) menjaga spirit perjuangan agar seluruh jajaran pengurus Salimah terus istiqomah mengusung visi bersama yaitu menjadikan 
Salimah sebagai organisasi massa muslimah yang dinamis dalam meningkatkan kualitas hidup perempuan, keluarga dan anak Indonesia (www.salimah.or.id, 2020). Salimah menghadapai berbagai tantangan dalam mencapai target program organisasi. Secara umum Salimah Kota Bandar Lampung menghadapi permasalahan dalam mencapai tujuan organisasi, yakni:

a. Minimnya partisipasi pengurus daerah Salimah Kota Bandar Lampung

b. Program kerja yang berjalan hanya mencapai angka 35\%

c. Tidak ada sinergitas program antara Pengurus Kecamatan dengan Pengurus Daerah Salimah Kota Bandar Lampung

Identifikasi permasalahan yang tertera di atas berpangkal dari data-data yang diperoleh berupa kondisi struktur organisasi salimah tingkat kecamatan.

Tabel 1. Kondisi Struktur Organisasi Salimah Tingkat Kecamatan

\begin{tabular}{clc}
\hline NO & \multicolumn{1}{c}{ KECAMATAN } & STRUKTUR \\
\hline 1. & Bumi Waras & Tidak Aktif \\
2. & Enggal & Aktif \\
3. & Kedamaian & Aktif \\
4. & Kedaton & Aktif \\
5. & Kemiling & Aktif \\
6. & Labuhan Ratu & Tidak Aktif \\
7. & Langkapura & Aktif \\
8. & Panjang & Tidak Aktif \\
9. & Rajabasa & Tidak Aktif \\
10. & Sukabumi & Tidak Aktif \\
11. & Sukarame & Tidak Aktif \\
12. & Tanjung Seneng & Tidak Aktif \\
13. & Tangjung Karang Barat & Tidak Aktif \\
14. & Tangjung Karang Pusat & Aktif \\
15. & Tangjung Karang Timur & Aktif \\
16. & Teluk Betung Barat & Tidak Aktif \\
17. & Teluk Betung Selatan & Tidak Aktif \\
18. & Teluk Betung Timur & Tidak Aktif \\
19. & Teluk Betung Utara & Tidak Aktif \\
20. & Way Halim & Aktif \\
\hline
\end{tabular}

Sumber: Data diolah oleh tim PKM, 2020

Berikutnya terkait pelaksanaan program diketahui bahwa lebih dari 50\% program organisasi Salimah tidak berjalan sesuai target yang ditetapkan. 
Tabel 2. Pelaksanaan Program Kerja PD Salimah Kota Bandar Lampung

\begin{tabular}{clc}
\hline NO. & \multicolumn{1}{c}{ PROGRAM KERJA } & KETERANGAN \\
\hline 1. & Koperasi Jasa Keuangan Salimah (KJKS) & Berjalan \\
2. & Sekolah Ibu Salimah Terpadu (Sister) & Tidak berjalan \\
3. & Gerakan Membaca Al-Qur'an (Gema Salimah) & Tidak berjalan \\
4. & Koperasi Syari'ah Serba Usaha Salimah (KOSSUMA) & Berjalan \\
5. & Baitul Qur'an Salimah (BQS) & Tidak berjalan \\
6. & Forum Silaturahim Majlis Taklim (Forsil MT) & Tidak berjalan \\
7. & Pelatihan Kepribadian Muslimah & Tidak berjalan \\
8. & Pos Peduli Anak Yatim (P2AY) & Berjalan \\
9. & Pos Penanggulangan Musibah dan Bencana (P2MB) & Tidak berjalan \\
10. & Pelatihan Kepemimpinan Pengurus Salimah & Tidak berjalan \\
11. & Gaya Hidup Sehat dan Hijau & Tidak berjalan \\
12 & Salimah Cyber Team & Berjalan \\
13. & Program pengembangan wilayah (kecamatan) & Tidak berjalan \\
\hline
\end{tabular}

Sumber: Data diolah oleh tim PKM, 2020

Uniati (2014) menyatakan efek positif yang kuat dari learning organization terhadap kinerja organisasi terbentuk melalui kepuasan kerja dan komitmen organisasi. Organisasi harus melakukan perubahan secara terus menerus dan kreatif, untuk mencari ide dan inovasi dengan cara menerapkan pembelajaran dalam organisasinya sehingga menjadi organisasi pembelajar (learning organization). Hanya organisasi yang mau mengembangkan institusinya menjadi organisasi pembelajar, mau belajar dan meningkatkan diri secara terus menerus akan menjadi organisasi yang unggul (Wiyono, 2017).

Dimensi Learning Organization (Senge, 1996) mengemukakan bahwa di dalam learning organization yang efektif diperlukan 5 dimensi yang akan memungkinkan organisasi untuk belajar, berkembang, dan berinovasi yakni:

1. Personal mastery (keahlian pribadi). Penguasaan pribadi adalah disiplin yang terus memperjelas dan memperdalam visi pribadi, memfokuskan energi, mengembangkan kesabaran, dan melihat realitas obyektif. Visi adalah panggilan bukan hanya sekedar ide yang baik. Orang dengan penguasaan pribadi tingkat tinggi hidup dalam modus belajar terus menerus. Orang dengan penguasaan pribadi tingkat tinggi sangat sadar akan kebodohan mereka, ketidakmampuan mereka, daerah pertumbuhan mereka, namun mereka sangat percaya diri. Mulyono \& Kresnaini (2015) bahwa learning organization berpengaruh langsung terhadap kemampuan individual

2. Mental models (model mental). Hal ini adalah asumsi yang tertanam, generalisasi, atau bahkan gambar. Gambar yang mempengaruhi bagaimana kita memahami 
dunia dan bagaimana kita mengambil tindakan. Kita sering tidak menyadari dampak dari asumsi seperti pada perilaku kita, dengan demikian bagian mendasar dari tugas kita adalah untuk mengembangkan kemampuan untuk mencerminkan tindakan. Disiplin model mental dimulai dengan memutar cermin diri; belajar untuk menggali gambar internal kita dari dunia, untuk membawa mereka ke permukaan dan menahan mereka secara ketat untuk pemeriksaan. Hal ini juga termasuk kemampuan untuk melakukan 'learningful', di mana orang mengungkapkan pemikiran mereka sendiri secara efektif dan membuat berpikir terbuka terhadap pengaruh orang lain.

3. Shared vision (visi bersama). Membangun rasa komitmen dalam suatu kelompok, dengan mengembangkan gambaran bersama tentang masa depan yang akan diciptakan, prinsip dan praktek yang menuntun cara kita mencapai tujuan masa depan tersebut. Visi itu memiliki kekuatan untuk meningkatkan dan mendorong eksperimentasi dan inovasi. Senge (1996) berpendapat bahwa itu juga dapat menumbuhkan kekuatan jangka panjang, yang merupakan dasar dari 'disiplin kelima dalam bukunya. Praktek visi bersama melibatkan keterampilan menggali bersama 'gambar masa depan' bahwa komitmen adalah motif dasar manusia bukan hanya karena kepatuhan seseorang. Visi menyebar karena ada proses penguatan.

4. Team learning (pembelajaran tim). Disiplin belajar tim dimulai dengan 'dialog', kapasitas anggota tim untuk menangguhkan asumsi dan masuk ke dalam suatu kesatuan berpikir bersama. Bagi orang Yunani dialog artinya logos yang berarti bebas-mengalir jika makna melalui kelompok, yang memungkinkan kelompok untuk menemukan wawasan dan tidak dicapai secara individual. Itu juga mencakup belajar bagaimana mengenali pola-pola interaksi dalam tim yang melemahkan belajar. Senge berpendapat, ada kemungkinan untuk menciptakan bahasa yang lebih cocok untuk menangani kompleksitas, dan berfokus mendalam pada masalah struktural bukannya dialihkan oleh pertanyaan dari gaya kepribadian dan kepemimpinan. Mentransformasikan pembicaraan dan keahlian berpikir (thinking skills) sehingga suatu kelompok dapat secara sah mengembangkan otak dan kemampuan yang lebih besar dibandingkan ketika masing-masing anggota kelompok bekerja sendiri.

5. System thinking (berpikir sistem). Berpikir sistemik adalah landasan konseptual (The Fifth Discipline) dari pendekatannya. Ini merupakan disiplin yang mengintegrasikan orang lain, menggabungkan mereka menjadi suatu tubuh yang koheren antara teori dan praktek. Kemampuan sistem teori untuk memahami dan mengatasi keseluruhan, dan untuk memeriksa keterkaitan antara bagian-bagian yang menyediakan, baik insentif dan sarana untuk mengintegrasikan disiplin ilmu. Senge (1996) berpendapat bahwa salah satu masalah utama yang banyak yang ditulis, dan dilakukan atas nama manajemen, adalah bahwa kerangka kerja yang 
agak sederhana diterapkan untuk sebuah sistem yang kompleks. Orang cenderung untuk berfokus pada bagian parsial daripada melihat keseluruhan, dan gagal untuk melihat organisasi sebagai proses dinamis. Dengan demikian argumen tidak berjalan, apresiasi yang lebih baik dari sistem akan tidak mengarah pada tindakan yang lebih tepat. Peter Senge mendukung penggunaan 'sistem peta', diagram yang menunjukkan elemen kunci dari sistem dan bagaimana mereka terhubung. Orang perlu melihat masalah sistem, dan dibutuhkan kerja untuk memperoleh blok bangunan dasar dari teori sistem, dan menerapkannya pada organisasi.

Kegiatan pengabdian ini bertujuan memecahkan permasalah mitra seperti yang sudah teridentifikasi tersebut sehingga diharapkan dapat memberikan nilai manfaat berupa: kesadaran berorganisasi Pengurus Daerah dan Kecamatan Kota Bandar Lampung; tercapainya visi dan misi serta program-program organisasi Salimah; serta timbul sinergitas program antara pengurus cabang dan pengurus daerah.

\section{METODE PELAKSANAAN}

Optimalisasi kapabilitas Pengurus Salimah Kota Bandar Lampung melalui Learning Organization dilaksanakan pada minggu ke empat bulan Agustus 2020 dengan menggunakan platform Zoom meeting. Secara ringkas metode dan tahap pelaksanaan kegiatan pengabdian ini terdeskripsikan dalam gambar berikut.

\begin{tabular}{|c|c|c|}
\hline $\begin{array}{c}\text { ANALISIS } \\
\text { SITUASI } \\
\text { Studi pustaka } \\
\text { dan lapangan }\end{array}$ & \begin{tabular}{l}
\multicolumn{1}{l}{ INTERVENSI } \\
\multicolumn{1}{c}{ OBJEK } \\
Ceramah, FGD \\
dan Pendampingan
\end{tabular} & $\begin{array}{l}\text { EVALUASI } \\
\text { Evaluasi } \\
\text { kuantitatif dan } \\
\text { kualitatif }\end{array}$ \\
\hline
\end{tabular}

Gambar 1. Metode dan Tahap Pelaksanaan

Sumber: diolah oleh tim PKM, 2020

Analisis situasi dilakukan dengan studi pustaka dan studi lapangan. Tahap pelaksanaan melaui ceramah, diskusi/ tanya jawab selama proses pemaparan materi. Tahap evaluasi dilakukan secara kuantitatif pre-test dan post-test serta evaluasi kualitatif. 


\section{PELAKSANAAN DAN HASIL}

Optimalisasi kapabilitas Pengurus Persaudaraan Muslimah (Salimah) Kota Bandar Lampung melalui Learning Organization yang dilaksanakan secara daring dengan menggunakan platform Zoom meeting merupakan hasil konsensus yang dilakukan oleh tim pengabdian dan mitra ditengah merebaknya wabah pandemi Covid-19. Penggunaan platform Zoom meeting menjadi pilihan solutif dengan maksud tetap menjaga keamanan dan kenyamanan seluruh partisipan kegiatan pengabdian tanpa mengurangi nilai faedah dari kegiatan pengabdian.

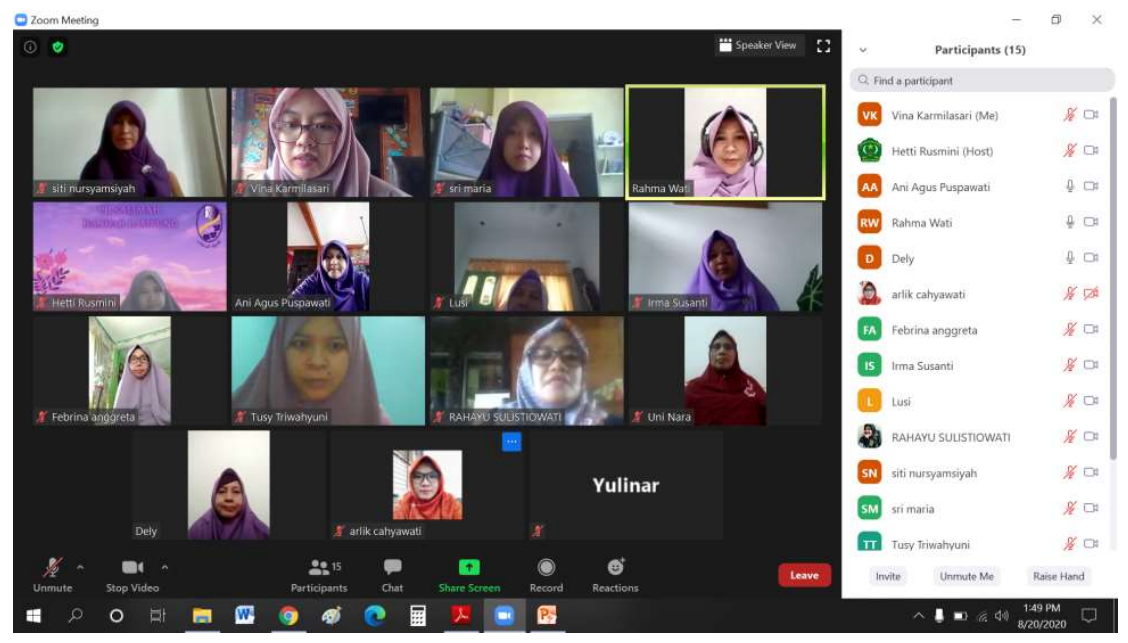

Gambar 2. Pelaksanaan PKM secara Daring

Sumber: Dokumentasi oleh tim PKm, 2020

Rangkaian kegiatan pelaksanaan pengabdian dimulai dengan ice breaking berupa permainan online, selanjutnya pre-test, pemberian materi dan pelaksanaan posttest. Secara lengkap susunan acara kegiatan terinci sebagai berikut:

Tabel 3. Jadwal Pelaksanaan PKM

\begin{tabular}{|c|c|c|c|}
\hline WAKTU & ACARA & PETUGAS & KET \\
\hline $08.00-08.30 \mathrm{WIB}$ & $\begin{array}{l}\text { Persiapan dan Registrasi } \\
\text { peserta }\end{array}$ & Panitia & Daftar hadir \\
\hline $08.30-09.00 \mathrm{WIB}$ & $\begin{array}{l}\text { a. Pembukaan } \\
\text { b. Sambutan Ketua } \\
\text { Pelaksana } \\
\text { c. Sambutan Ketua PD } \\
\text { Salimah Kota Bandar } \\
\text { Lampung } \\
\text { d. Doa } \\
\end{array}$ & Panitia & \\
\hline $09.00-09.20 \mathrm{WIB}$ & Pre-test & Panitia & $\begin{array}{l}\text { Soal pre test dengan } \\
\text { google form }\end{array}$ \\
\hline $09.20-09.40$ WIB & $\begin{array}{l}\text { ICE BREAKING: ga me } \\
\text { online }\end{array}$ & Panitia & \\
\hline
\end{tabular}




\begin{tabular}{|c|c|c|c|}
\hline \multirow[t]{3}{*}{$09.40-11.20 \mathrm{WIB}$} & $\begin{array}{l}\text { Materi I: mental model } \\
\text { dan personal mastery }\end{array}$ & Ani Agus Puspawati, & \multirow[t]{3}{*}{ Materi dan diskus } \\
\hline & $\begin{array}{l}\text { Materi II: shared vision, } \\
\text { team learning }\end{array}$ & $\begin{array}{l}\text { Susana Indri } \\
\text { Caturiani, S.IP, M.Si. }\end{array}$ & \\
\hline & $\begin{array}{l}\text { Materi III: : komunikasi } \\
\text { efektif }\end{array}$ & $\begin{array}{l}\text { Rahayu Sulistiowati } \\
\text { S.Sos, M.Si. } \\
\text { Vina Karmilasari, } \\
\text { M.Si. }\end{array}$ & \\
\hline $11.20-11.40 \mathrm{WIB}$ & Post-test & Panitia & Soal post test \\
\hline $11.40-12.00 \mathrm{WIB}$ & PENUTUP: & $\begin{array}{l}\text { Seluruh } \\
\text { narasumber }\end{array}$ & $\begin{array}{l}\text { Lembar } \\
\text { Komitmen }\end{array}$ \\
\hline
\end{tabular}

Sumber: diolah oleh tim PKM, 2020

Guna memecahkan permasalahan organisasi Salimah Kota Bandar Lampung dalam mencapai tujuan organisasi seperti yang diidentifikasi sebelumnya berikut kerangka pemecahan masalah yang dibuat oleh tim sebagai peta guna memudahkan penguraian masalah organisasi.

Tabel 4. Kerangka Pemecahan Masalah

\begin{tabular}{|c|c|c|}
\hline MASALAH & SOLUSI & LUARAN \\
\hline 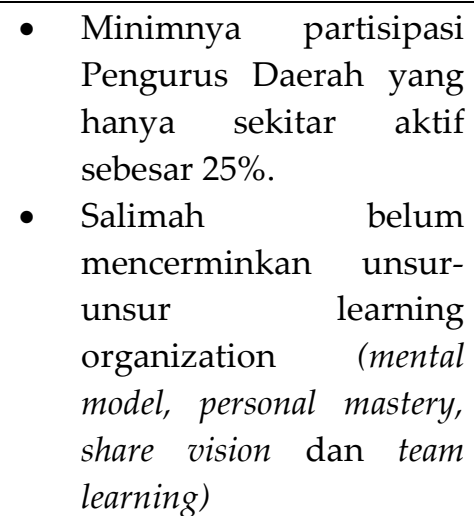 & 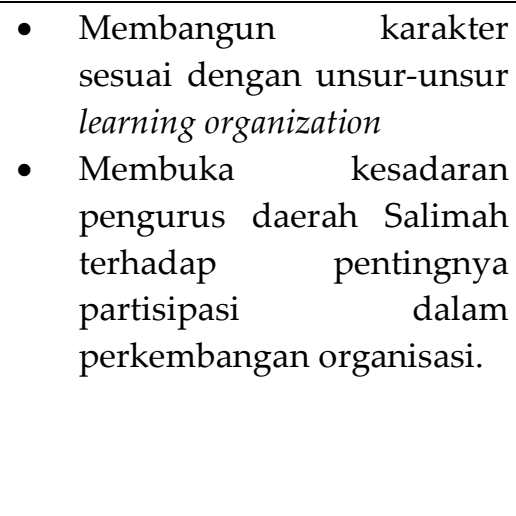 & $\begin{array}{l}\text { Tercipta learning organization } \\
\text { dalam organisasi Salimah serta } \\
\text { meningkatnya kesadaran } \\
\text { Pengurus Daerah dan } \\
\text { kecamatan terhadap pentingnya } \\
\text { partisipasi dalam } \\
\text { perkembangan organisasi guna } \\
\text { menyukseskan program kerja } \\
\text { bersama. }\end{array}$ \\
\hline $\begin{array}{l}\text { Program kerja tidak berjalan } \\
\text { dengan baik, hanya sebesar } \\
35 \% \text { program yang berjalan. }\end{array}$ & $\begin{array}{l}\text { Peningkatan efektivitas } \\
\text { pelaksanaan program kerja } \\
\text { dengan membuat perencanaan } \\
\text { yang jelas. }\end{array}$ & $\begin{array}{l}\text { Tujuan pelaksanaan program } \\
\text { tercapai dengan baik. }\end{array}$ \\
\hline $\begin{array}{l}\text { Tidak ada sinergi program } \\
\text { antara pengurus tingkat } \\
\text { kecamatan dan pengurus } \\
\text { daerah. }\end{array}$ & $\begin{array}{l}\text { Membentuk sinergitas program } \\
\text { antara pengurus tingkat } \\
\text { kecamatan dan pengurus } \\
\text { daerah. }\end{array}$ & $\begin{array}{l}\text { Adanya sinergitas pelaksanaan } \\
\text { program kerja dari pengurus } \\
\text { cabang dan pengurus daerah } \\
\text { sehingga komunikasi dalam } \\
\text { pelaksanaan program dapat } \\
\text { dilaksanakan dengan baik. }\end{array}$ \\
\hline
\end{tabular}

Sumber: diolah oleh tim PKM, 2020

Berdasar pada kerangka pemecahan masalah tim pengabdian melakukan intervensi objek melalui ceramah dengan tema mental model dan personal mastery; share vision, 
team learning; serta komunikasi efektif. Forum group discussion dengan menghadirkan para narasumber sebagai pemateri sesuai dengan bidang kepakaran yang dimiliki.

Pemaparan materi pertama dilakukan oleh Ani Agus Puspawati dan Susana Indri Caturiani dengan judul mental model dan personal mastery. Materi ini disampaikan dengan cara ceramah dan melibatkan peserta untuk berbagi cerita tentang pengalaman mereka dalam Salimah Kota Bandar Lampung. Dari kegiatan berbagi cerita ini pemateri mendapatkan gambaran bahwa Pengurus Daerah Salimah Kota Bandar Lampung belum memahami pentingnya mental model dan personal mastery dalam organisasi pembelajar.

Pemateri ketiga Rahayu Sulistiowati menyampaikan materi shared vision, team learning. Pemahaman mengenai shared vision dan team learning menjadi salah satu aspek penting dalam mendukung peningkatan kapasitas pengurus organisasi. Materi tersebut bertujuan untuk membangun kerja sama tim dan visi bersama.

Materi berikutnya diberikan oleh Vina Karmilasari dengan tema komunikasi efektif. Materi ini diberikan dengan tujuan agar tercipta pemahaman tentang pentingnya komunikasi efektif dalam berorganisasi. Materi terkait unsur-unsur komunikasi, tujuan dan fungsi komunikasi efektif, serta hambatan-hambatan dalam komunikasi efektif disampaikan guna meningkatkan kapasitas pengurus daerah ormas salimah Kota Bandar Lampung.

Kegiatan pre-test dan post-test bertujuan untuk menilai perubahan kapabilitas peserta sebelum dan sesudah dilakukan pelatihan. Dengan menggunakan tools google formulir peserta diarahkan untuk menjawab pertanyaan yang diajukan dalam pre-test dan posttest. Hasil keseluruhan pre-test dan post-test tercantum dalam tabel berikut.

Tabel 5. Hasil Pre-test dan Post-test

\begin{tabular}{clccc}
\hline No & \multicolumn{1}{c}{ Nama } & Nilai Pretest & Nilai Postest & Perubahan \\
\hline 1. & Dely Marlina Mardanis & 74 & 83 & 9 \\
2. & Febrina Anggreta & 70 & 76 & 6 \\
3. & Hetti Rusmini & 75 & 83 & 8 \\
4. & Irma Susanti & 63 & 75 & 12 \\
5. & Lusi & 74 & 82 & 8 \\
6. & Nahara & 69 & 78 & 9 \\
7. & Rahmawati & 70 & 74 & 4 \\
8. & Siti Nursyamsiyah & 70 & 80 & 10 \\
9. & Sri Maria Puji Lestari & 75 & 83 & 8 \\
10. & Yulinar & 73 & 80 & 7 \\
11. & Puspa & 75 & 83 & 8 \\
12. & Arlik & 74 & 81 & 7 \\
13. & Tusi & 74 & 81 & 7 \\
14. & Rika & 72 & 76 & 4 \\
15. & Rahayu Lestari & 70 & 76 & 6
\end{tabular}




\begin{tabular}{lllll} 
16. & Bani & 64 & 66 & 2 \\
17. & Reni & 70 & 74 & 4 \\
18. & Widi & 68 & 75 & 7 \\
19. & Erna & 60 & 72 & 12 \\
20. & Khasanah & 65 & 75 & 10 \\
\hline
\end{tabular}

Sumber: diolah oleh tim PKM, 2020

Secara kuantitatif nilai rata-rata peserta sebelum dilaksanakan kegiatan adalah 70,25 dan mengalami kenaikan menjadi 77,65 setelah dilaksanakan kegiatan pelatihan. Kenaikan rata-rata sebesar 7,4 poin. Baik nilai pre test maupun post test tertinggi adalah 83 dan nilai terendah 60 . Berdasarkan hasil tersebut di atas maka dapat disimpulkan bahwa kegiatan pengabdian ini mampu memberikan dampak positif secara kognitif terhadap pengetahuan tentang Learning Organization. Sedangkan dari sisi afektif peserta menjadi lebih memahami unsur-unsur terbentuknya Learning Organization. Dengan demikian keberhasilan organisasi lebih mudah diwujudkan.

\section{PENUTUP}

Berdasarkan hasil yang telah dipaparkan di atas dapat disimpulkan bahwa secara keseluruhan kegiatan PkM dengan judul Literasi Learning Organization pada Pengurus Persaudaraan Muslimah (Salimah) Kota Bandar Lampung mampu memberikan dampak positif secara kognitif terhadap pengetahuan tentang Learning Organization. Sedangkan dari sisi afektif peserta menjadi lebih memahami unsurunsur terbentuknya learning organization.

\section{UCAPAN TERIMA KASIH}

Ucapan terima kasih dihaturkan kepada partisipan terkhusus Ormas Salimah Kota Bandar Lampung sebagai mitra dalam kegiatan PKM yang telah memberikan dukungan moril dan materil sehingga kegiatan PKM ini dapat berfaedah. Terima kasih kepada LPPM Universitas Lampung atas pendanaan PKM melalui Hibah BLU DIPA UNILA Pengabdian Skema Pemula tahun 2020.

\section{DAFTAR PUSTAKA}

Mulyono, S. \& Kresnaini, E. (2015). Memetakan Perubahan Organisasi dalam Desain Learning Organization pada Usaha Kecil Menengah di Kota Malang. Jurnal Ekonomi dan Bisnis, XVIII.

Senge, P. M. (1996). Disiplin Kelima Seni \& Praktek dari Organisasi Pembelajar. Jakarta: Binarupa Aksara.

Uniati, M. Ida. (April 2014). Learning Organization, Komitmen Pada Organisasi, Kepuasan Kerja, Efektivitas Penerapan Sistem ISO dan Dampaknya Terhadap 
Kinerja Organisasi (Studi Kasus Staf Administrasi UK Petra Surabaya). Jurnal Manajemen Pemasaran, 8(1).

Wiyono, G. (2017). Strategi Penerapan Organizational Learning Untuk Membentuk Guru Pembelajar di Sekolah. Jurnal Edukasi Elektro.

https://www.salimah.or.id/ diakses pada 12 Februari 2020 pukul 10.30 WIB 